VISNYK LVIV UNIV.

ерія геогр. 2011. ип. 39. .95-112 Ser. Geogr. 2011. N 39. P. 95-112

$551.79(467)$

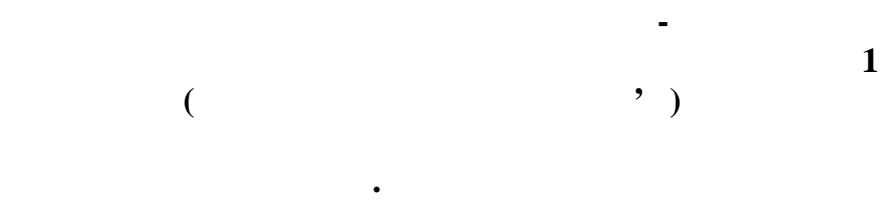

ьвівський н ціон льний університет імені в н вул. . орошенк , 41, м. ввів, 79000, кр їн

ет льно опис но м сшт бне відслонення - один з н йцік віших і н йцінніших у стр тигр фічному т п леогеогр фічному спект х розрізів верхньоплейстоценового грунтово-лесового покриву кр їнського рик рп ття - лицького ридністер'я. иділено т сх р ктеризов но нові, не відзн чені попередніми дослідник ми, горизонти місцевого неоплейстоцену. овий ф ктичний м тері л спонук є змінити суч сні уявлення про стр тигр фічне положення й вік головного культурного ш ру межигірської п леолітичної стоянки.

лючові слов : верхній плейстоцен, грунтово-лесовий покрив, пізній п леоліт, ежигірці 1.

окрив четвертинних відкл дів, розкритий у верхньому ярусі великого мергельного к р'єру біля с. ежигірці лицького р-ну в но- p нківської обл. ст в об'єктом геологічних досліджень з вдяки н явності культурного ш ру ( ) пізньоп леолітичного віку, б г того н крем'яні вироби т кістяні рештки. опри те, що зн чн , , можливо, $і$ більш ч стин п леолітичного поселення, про існув ння якого ст ло відомо влітку 1975 р., уже бул знищен вн слідок з кл д ння т експлу т ції к р'єру, ежигірськ стоянк, відом в літер турі як ежигірці 1, ст л н йб г тшою п м'яткою пізнього п леоліту кр їнського рик рп ття - лицького ридністер'я $[6,11]$.

ивченню п леолітичної стоянки сприяли висок концентр ція ртеф ктів (сотні

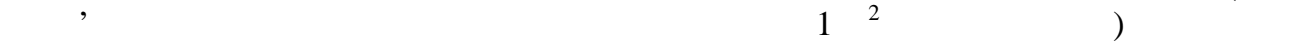
(до 2 м) глибин їхнього з ляг ння. ст ння обст вин р зом зі стр тигр фічною неповнотою розрізу верхньоплейстоценових відкл дів т відсутністю $\mathrm{p}$ діометричних д тув нь суттєво ускл днил точне й однозн чне визн чення стр тигр фічної позиції головного п м'ятки і, відповідно, його геологічного й бсолютного віку. годом, коли для стоянки було отрим но р діовуглецеві д ти - спершу дві близькі (17 $560 \pm$ $270 ; 17200 \pm 250)$, потім ще одну (20 $360 \pm 200)$, що розходил сь 3 попередніми [6, 20], пит ння щодо хроностр тигр фічної позиції ш ру не отрим ло однозн чного вирішення не лише через неузгодженість р діометричних д тув нь, й через деяку невідповідність двох перших визн чень д т техніко-типологічному вигляду к м'яної індустpiї [4]. ільк років тому сформув лось уявлення про те, що стоянк ежигірці 1 уже не існує - п м'ятк повністю знищен як ре льний об'єкт ун слідок експлу т ції к р'єpy [6].

озширення верхнього ярусу ежигірського к р'єру, систем тично здійснюв не протягом кількох ост нніх років, суттєво поліпшило відслоненість покриву четвертинних відкл дів і розкрило місцями досить потужну (до 10-12 м) товщу плейстоцену, в середній ч стині якої н різних ділянк х відслонення ми н весні 2007 р. виявили окремі

(C) н тюК ., 2011 
вироби з кременю т інші сліди перебув ння д вньої людини. н хідки спонук ли до дет льнішого вивчення розрізу, у ході якого було з'ясов но, що він цік вий і цінний с м по собі передусім у стр тигр фічному, т кож і п леогеогр фічному спект х. 'ясов но, зокрем , що у відслоненні розкрито нові, не відзн чені попередніми дослідник ми, горизонти місцевого неоплейстоцену. 'явил сь можливість отрим ти новий ф ктичний м тері л щодо головного ежигірської п леолітичної стоянки т уточнити його положення у стр тифіков ному покриві верхньоплейстоценових відкл дів. исвітленню результ тів польових робіт, спрямов них н вивчення будови т стр тигр фії цього покриву, й присвячен пропонов н пр ця.

осліджений розріз приурочений до вирівняної вододільної поверхні - вершини г. ерштов ( ерстов ), т пологого привододільного схилу, що з міщує їі у північному н прямі (рис. 1). і елементи рельєфу відділяють ерозійно-денуд ційний уступ долини ністр від долини невеликого водотоку - лівобічного допливу р. ибелки.

йвищ ділянк вершини гори, обмежен ізогіпсою 325 м, гіпсометрично відповід $\epsilon$ покрівлі горизонту міоценових гіпсів, відслонених у центр льній і південній ч стин х верхнього ярусу к р'єру. ей ф кт з свідчує їі структурно-денуд ційне походження. івденно-з хідн ч стин вершинної поверхні знищен вн слідок гірничих робіт; брівк к р'єру місцями уже перетнул іiї вододіл.

гідно з опис ми рхеолог . л пчук $[7,10]$, який розпоч в розкопки межигірської п м'ятки, рештки п леолітичної стоянки виявлено у центр льній ч стині г. ерштов в меж х її вершинної поверхні. стоянки, фіксов ний к м'яними вироб ми, х отичними скупченнями кісток тв рин і лінз ми золи, що з ляг ли кільком з'єдн ними бо ізольов ними ярус ми, леж в у верхній ч стині лесового покриву під грунтом чорноземоподібного типу. одному з розкопів він був розкритий н глибині 1,50-1,65 м. отужність ш ру не перевищув л 0,4 м $[10,11]$.

ерший кв ліфіков ний опис покривних відкл дів р йону стоянки викон ний н прикінці 70-х років [1]. ізу льне дослідження четвертинного покриву, потужність якого досяг л і перевищув л 5 м, д ло змогу . д менку виділити шість головних ш рів, у тім числі бурий вилугув ний викопний грунт ( $)$, розміщений у верхній ч стині покриву н глибині 1,5-1,7 м. о цього грунту був приурочений головний п м'ятки; с м грунт зіст влений з вит чівським горизонтом стр тигр фічної схеми четвертинних відкл дів кр їни.

овий опис розрізу, зроблений у 80-ті роки т доповнений з розчистк ми 1995 i 1999 рр., опис ний у публік ціях [17, 19, s. 81-83]. гідно з дослідженнями, проведеними головно . огуцьким, п м'ятки відповід є верхній ч стині суб рктичного

, що зіст влений з рівненським горизонтом грунтово-лесової товщі верхнього плейстоцену олино- оділля - відповідником дофінівського горизонту стр тигр фічної схеми четвертинних відкл дів кр їни. г лом у розрізі потужністю 5,6 м під експонов ним грунтом виділено три горизонти лесу, дв сл бко виявлені горизонти оглеєння т вище з зн чений похов ний грунт ( ) буроземного типу, розміщений н глибині 1,60-1,85 м [19].

ольові дослідження, проведені влітку т восени 2007 р. т у липні 2008 р., перед6 ч ли візу льне вивчення геологічної будови покриву четвертинних відкл дів 3 використ нням літологічного т п леопедологічного методів. ет льно вивчено покрив у вибр них місцях - т м, де він був порівняно добре відслонений і доступний для безпосередніх досліджень. кі фр гменти відслонення довжиною від кількох до 20-25 м були н зв ні розріз ми (розріз , т ін. н рис. 1). меж х кожного розрізу зроблено 
кільк розчисток, розміщених н різних рівнях відслонення. роблено спробу простежити виділені й опис ні ш ри вздовж усієї стінки верхнього ярусу к р'єру. ля лок ліз ції опр цьов них розрізів використ но космознімок, що зобр ж в ст н місцевості у жовтні 2006 р.

осліджений розріз, беручи до ув ги особливос-ті будови т з ляг ння товщі четвертинних відкл дів, можн розділити н дві неодн -кові з довжиною ч стини - порівняно коротку північну т зн чно довшу південну. північній ч стині відслонення четвертинний покрив 3 ляг $є$ н м йже рівній, злегк н хиленій згідно 3 п дінням суч сного схилу поверхні звітрених мергелів верхньої крейди, у південній - н вир зно нерівній поверхні з к рстов них міоценових гіпсів, перекритих місцями глин ми косівської світи (верхній б ден середнього міоцену). зн чені фр гменти відслонення суттєво відрізняються з потужністю т стр тигр фічною повнотою розрізу; їм відповід ють різні елементи рельєфу:

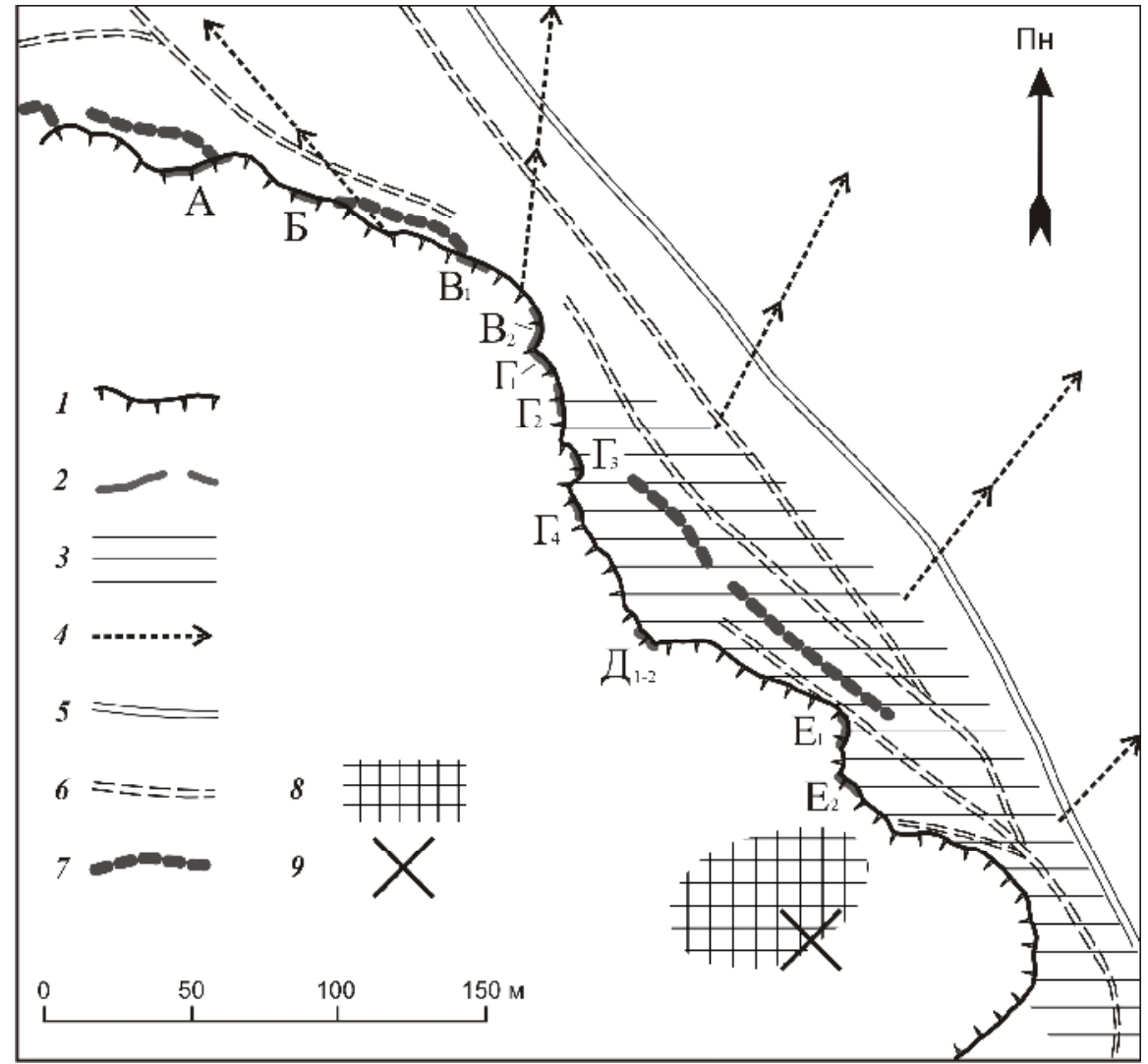

ис. 1. озміщення розрізів, опис них під ч с вивчення будови четвертинного покриву, розкритого у верхньому ярусі ежигірського к р'єру (ситу ція ст ном н 2007 р.): 1 - стінк верхнього ярусу к р'єру; 2 - розрізи, опис ні в тексті, їхні символи; 3 - вершинн поверхня г. ерштов ; 4-н прям п діння привершинних схилів; 5 - польов дорог ; 6-тимч сові дороги, створені під ч с розширення к р'єру; 7 - земляні в ли, розміщені біля брівки к р'єру; 8 - н йвищ ділянк вершинної поверхні г. ерштов ; 9 - передб чув ний центр головного п леолітичного поселення. 
північний фр гмент розміщений у меж х пологого привододільного схилу північної т північно-з хідної експозицій, південному відповід є вирівнян вододільн поверхня, н йвищі ділянки якої вироблені по покрівлі горизонту гіпсів. північній ч стині відслонення потужність т інші х р ктеристики покриву поступово змінюються 3 простяг нням, у південній, н вп ки, вони дуже мінливі т 3 леж ть передусім від головних (вир жених у суч сному рельєфі) і другорядних (похов них під чохлом четвертинних відкл дів) нерівностей поверхні гіпсів міоцену.

північній ч стині відслонення опр цьов но чотири розрізи - , , $1, \quad 2$ (див. рис. 1). озріз 1 відобр ж є будову перехідної ділянки відслонення, інші сім х р ктери-зують його південну ч стину.

ксим льн потужність покриву четвертинних відкл дів з фіксов н у розрізі , що розміщений з 45-70 м від північного кр ю верхньої стінки к р'єру. ей же розріз ст в опорним для стр тигр фії четвертинного покриву усього відслонення. огляду н це опис дослідженої стінки к р'єру розпочнемо з дет льної х р ктеристики ш рів с ме цього розрізу.

1. кспонов ний грунт (0,0-1,3/1,4 м) темно-сірий лісовий, близький до чорнозему опідзоленого, з ч стково чи повністю знищеними к р'єрними робот ми гумусовоелюві льним гор. . ор. скл дений суглинк ми жовто-коричневими, м є призм тичну структуру т містить численні червоточини й окремі кротовини до 10 см у ді метрі, шо виповнені м тері лом гор. . отужність гор. - до 1,2 м. ерехід до порід нижчого горизонту поступовий.

2. оризонт лесоподібних порід (1,4-5,0 м), розділений н підгоризонти:

2.1 (1,4-2,6 м) - суглинки п леві зі стовпч стою окремістю, 3 кротовин ми, що виповнені м тері лом експонов ного грунту, у верхній ч стині сл бко оглеєні. углинки вз ємодіють з соляною кислотою, містять к рбон тний псевдоміцелій. $р$ пляються щільні к рбон тні конкреції до 2 см у ді метрі. ерехід дуже поступовий;

$2.2(2,6-5,0$ м) - суглинки т супіски п леві, з лок льно розвиненими оглеєними прош рк ми, вир зно ш рув ті у нижній, місцями - середній і верхній ч стин х підгоризонту. ижня ч стин ш ру супіщ н , містить прош рки дрібнозернистого піску. усій товщі н явні кротовини т сп льні к мери землерийних тв рин, тр пляються дрібні (жорств'яні) ул мки хемогенного в пняку. углинки т супіски бурхливо з кип ють з соляною кислотою. рбон тних конкрецій нем . ерехід з звич й поступовий, місцями вир зний (ясний) бо різкий з ерозійним конт ктом.

3. лейовий горизонт (5,0-5,8 м) - суглинки сизув ті т сизув то-П леві з вохристими смуг ми оз лізнення у верхній ч стині, неш рув ті, к рбон тні, вологі, в'язкі т щільні. рідк тр пляються необк т ні ул мки хемогенного в пняку. р розбитий вузькими вертик льними тріщин ми, що проник ють у нижчий горизонт. ого потужність змінюється від 0,65 до 0,8 м. ерехід поступовий.

4. муг стий оглеєний горизонт (5,8-6,8 м) - суглинки смуг сто з б рвлені (перев ж ють прош рки сизув то-п левого т сизув то-блідо-коричневого кольору), у верхній ч стині явно т прихов но ш рув ті (у p зі звітрюв ння пород ділиться н тонкі верстви-пл стини) і м ксим льно оглеєні. углинки сл бко грегов ні, з кип ють із соляною кислотою т містять блідо-вохристі смужки епігенетичного оз лізнення. рідк тр пляються дрібні ул мки в пняку.

середній т нижній ч стин х горизонту н явні тонкі (до 2,5 см) лінзи т прош рки попелу (золи) з вуглин ми, які легко розтерти в порошок. верхній половині горизонту н різних ділянк х розрізу зн йдено кістки, що н леж ть, м буть, північному оленю. 
отужність горизонту поступово зрост є у південному н прямі від 0,8 до 1,0 м. ерехід поступовий, ч сто підкреслений звивистою смужкою оз лізнення, яку можн прийм ти з межу з нижчим горизонтом. 3 лізнений прош рок місцями утворює орт3 нд потужністю до 2 см.

5. охов ний грунт (6,8-7,6 м) не диференційов ний н генетичні горизонти суглинки блідо-коричневі, у верхній ч стині чи безпосередньо біля покрівлі ш ру з звич й вохристо-коричневі вн слідок епігенетичного оз лізнення, добре грегов ні (зернисто-грудкув т структур ), з дрібними з лізисто-м нг новими стяжіннями т чорними плям ми м нг ну, які місцями групуються у горизонт льно розміщені смуги. теpi л вгорі i, місцями, при підошві сл бко з кип $\epsilon$, ре гуючи н кислоту. ерехід поступовий.

північній ч стині розрізу н рівні верхнього конт кту виявлено тонкі верстви золи, інтерпретов ні як перевідкл дені рештки вогнищ .

6. оризонт лесоподібних порід (7,6-9,6 м), розділений н підгоризонти:

6.1 (7,6-8,8 м) - суглинки п леві неш рув ті, 3 дрібними чорними стяжіннями т різного розміру плям ми м нг ну, які подібні до плям у вищому горизонті. верхній ч стині ш ру видно ниткоподібні прош рки коричневого кольору - псевдофібри. углинки місцями сл бко з кип ють. ерехід до порід нижнього підгоризонту дуже поступовий;

6.2 (8,8-9,6 м) - суглинки блідо-п леві (у нижній ч стині сизув то-п леві), містять численні ул мки мергелю т в пняку, тр пляється г льк кв рцового пісковику. ерехід вир зний бо різкий. ри підошві ш ру н явні тонкі прош рки, скл дені м тері лом з нижнього горизонту.

7. муг сто-и рув тий горизонт (9,60-10,65 м), скл дений суглинк ми буру-в то-блідо-коричневими т бурув то-жовтими, з сизув тими т вохристими смуг ми оглеєння й оз лізнення, м нг новими і з лізисто-м нг новими стяжіннями. оризонт у верхній ч стині вир зно ш рув тий, містить ул мки мергелю т в пняку довжиною до 1 см і більше, нерівномірно з кип є, нижче - невир зно ш рув тий, з меншою кількістю ул мків, сл бко скип є. ерехід чіткий і вир зний з з б рвленням.

8. рихов нош рув тий горизонт (10,65-11,20 м), скл дений суглинк ми блідокоричневими (у нижній ч стині з сірим відтінком), прихов но ш рув тими, зі світлими плям ми оглеєння, коричнюв то-сірою й чорною пункту цією м нг ну. углинки сл бко ущільнені, безк рбон тні. ерехід з щільністю вир зний бо різкий; конт кт нерівний, ерозійний, з лок льними розмив ми, що виповнені ш рув тими супіщ но-суглинистими відкл д ми.

9. охов ний грунт лісового типу (11,2-12,4 м) 3 еродов ним гумусово-елюві льним горизонтом, скл дений безк рбон тними суглинк ми. м кроморфологічними озн к ми грунт розділений н горизонти:

(0-20 см) - суглинки коричневі, зі світлими плям ми оглеєння у нижній ч стині, ущільнені, з з лізисто-м нг новими стяжіннями;

g (20-45 см) - суглинки неоднорідно з 6 рвлені (сірув то-коричневі з численними світлими плям ми оглеєння), щільні;

$\mathrm{B}_{2} \mathrm{~g}$ (45-120 см і більше) - суглинки бурув то-коричневі з численними й порівняно крупними сизув тими плям ми оглеєння у верхній ч стині.

ід підошви розчистки до дн верхнього ярусу к р'єру (поверхні звітрених верхньокрейдових мергелів) близько 1,2 м. 
ерхні (1-5) горизонти опис ного розрізу легко простежити вздовж усієї північної ділянки верхньої стінки к р'єру. обре видно, зокрем , розміщений у середній ч стині четвертинного покриву горизонт оглеєння (гомогенно-глейовий), місцями зігнутий р зом з прилеглими ч стин ми суміжних ш рів у вир зні ш троподібні скл дки. івнічніше опис ного вище розрізу з зн чений горизонт менше оглеєний і м є меншу потужність (60-55 см). рост є, н томість, потужність верхнього , досяг ючи 90-95 см. верхній ч стині цього грунту з 15 м від північного кр ю відслонення зн йдено дв оброблені людиною ул мки кременю.

меж х середнього фр гмент північної ч стини відслонення (інтерв л 70-130 м від північного кр ю стінки верхнього ярусу к р'єру) виявлено і простежено м йже всі (окрім нижнього ) р ніше виділені горизонти, проте х р ктеристики їх дещо інші. окрем , потужність гор. 3 (гомогенно-глейового) поступово зменшується у південному н прямі від 0,70-0,65 до 0,55 м, гірше виявлен сизув тість 36 рвлення. муг стий оглеєний горизонт м є тут теж дещо меншу потужність, сл бше оглеєний. углинки горизонту сл бко з кип ють, ре гуючи н кислоту, бо не киплять. р ктерної для розрізу смужки оз лізнення, приуроченої до нижнього конт кту ш ру, тут з звич й нем .

середній ч стині цього фр гмент відслонення (розріз н рис. 1) н різних рівнях смуг стого оглеєного горизонту виявлено тонкі (до 4 см товщини) лінзи т прош рки коричневого, попелясто-сірого (попіл) і темно-сірого кольору, інтерпретов ні як рештки перевідкл деного . окремих лінз х і прош рк х т поз ними н явні розсіяні чи сконцентров ні у лінзоподібні скупчення вуглини. верхній ч стині ш ру н їхньому рівні тр пляються кістки, у тім числі ул мки рогів північного оленя. одному перерізі (зверху вниз) з звич й можн виділити дв -три 3 зн чені вище прош рки, рідше - чотири-п'ять. орівняно потужні т протяжні (до 5 м і більше) прош рки 3 ляг ють у нижній і середній ч стин х ш ру. ор. 5 (верхній ) тут м йже не проглеєний, коричнюв тий, у середній ч стині коричневий, м є грудкув то-зернисту структуру. отужність горизонту витрим н 3 простяг нням і колив ється від 75 до 85 см. ижчий ш р (гор. 6) подібний до відповідного горизонту попереднього розрізу. оризонти 7 і 8 у меж х розрізу відслонені пог но. урфув нням виявлено, що гор. 8 лежить бо н ч стково зденудов ному (гор. 9 розрізу ), бо (південн ч стин розрізу) безпосередньо н соліфлюкційно зміщеній “корі звітрюв ння” мергелів верхньої крейди.

ступний фр гмент північної ч стини відслонення (інтерв л 130-205 м) відповід є стінці великого цирку верхнього ярусу к р'єру. озчистки, зроблені н різних ділянк х цирку, з свідчили зн чні ф ці льні зміни окремих горизонтів четвертинного покриву, т кож “вип д ння” з розрізу його нижніх ш рів ун слідок їхнього поступового виклинюв ння в південному н прямі.

північній і центр льній ч стин х цирку х р ктерні озн ки п'яти верхніх горизонтів відслонення, визн чені у розріз х і , зберіг ються. звемо лише їхні відмінні риси. ередусім поступово, ле досить помітно (до 2,5 м) зменшується потужність гор. 2. ідгоризонт 2.2 вирізняє н явність вохристих смуг оз лізнення т порівняно потужних прош рків піску. смуг стому оглеєному горизонті тонкі прош рки й лінзи перевідкл деного тр пляються рідше, ніж у розрізі , і м ють порівняно незн чну довжину. верхній ч стині ш ру тр пляються дрібні ул мки кременю, кістяні рештки виявлено лише у північній половині цирку. іля його північного кр ю у верхній ч стині горизонту зн йдено бивень м монт . 
меж х центр льної ділянки стінки цирку (розріз 1 н лісовим грунтом з ляг ють неш рув ті лесоподібні суглинки 3 дрібними ул мк ми хемогенного в пняку (інтерв л 1,6-2,2 м), підстелені товщею супіщ но-суглинистих і піщ но-супіщ них ш рув тих відкл дів з жорствою т щебенем в пняку (інтерв л 2,23,9 м). рув ті відкл ди перекрив ють смуг стий оглеєний горизонт, що відповід $є$ гор. 3 і 4 вище опис них розрізів. нижній ч стині покриву з ляг є дещо зденудов ний коричнюв тий грунт (5,1-5,5/5,6 м), виявлений у попередніх розріз х; під видно ш р лесоподібних порід, підстелений вир зно ш рув тими піш нистими відкл д ми, що містять ул мки в пняку. ижче з ляг є смуг стий ш рув тий горизонт - н лог гор. 7 і 8 розрізу , скл дений перев жно жовто-бурим суглинком. е нижче з фіксов н соліфлюкційно зміщен “кор звітрюв ння” к рбон тних порід з ул мк ми хемогенних в пняків міоценового віку; зн йдено ул мок к рп тського роговик .

ідсутність у центр льній і північній ч стин х цирку нижнього (гор. 9 опорного розрізу) підтверджує здог д про те, що гор. 7 і 8 розрізів і скл дені головно м теpi лом, н гром дженим ун слідок знесення нижніх ( $\mathrm{i})$ т верхніх ( $\mathrm{i}$ ) горизонтів цього грунту, крупноул мковий м тері л підгоризонту 6.2 т гор. 7 перевідкл дений з “кори звітрюв ння” верхньої крейди т міоцену.

південній ч стині цирку через н явність п леоулоговини, якій у суч сному рельєфі відповід є ледь помітне зниження, усі верхні горизонти плейстоцену поступово н був ють вир зних озн к оглеєння, потужність експонов ного грунту помітно зрост є. 25-30 м від південного кр ю цирку гомогенно-глейовий горизонт і н був ють вохристо-жовтого (блідо-іржистого) відтінку, у смуг стому оглеєному горизонті 3'являються з лізисто-м нг нові новоутворення до 5 мм у ді метрі. ри підошві смуг стого горизонту т у верхній ч стині (до глибини $10 \mathrm{~cm}$ ) тр пляються перев жно дрібні вироби з кременю. н йдено необроблений ул мок роговик .

кр йній південній ч стині цирку (інтерв л 170-190 м) розчищено всі горизонти покриву четвертинних відкл дів. ут опр цьов но розріз 2 , стислий опис якого н водимо нижче.

1. кспонов ний грунт (0,0-2,3 м), скл дений безк рбон тними суглинк ми, розділений н горизонти: $\quad$ (0-70 см) - темно-сірий, у середній ч стині до чорного; $\quad$ (70170 см) - жовтув то-коричневий, з червоточин ми т кротовин ми, виповненими м теpi лом гор. ; н явні чорні прим зки н стінк х тріщин т іржисті плями оглеєння; $\mathrm{BCg}$ (170-230 см) - жовтув то-блідо-коричневий, з сизув тими т іржистими плям ми оглеєння.

2. лейовий горизонт (2,30-2,85 м) - суглинки сизув того т сизого кольору, 3 вохристими смуг ми т плям ми, к рбон тні, містять дрібні ул мки в пняку. отужність горизонту зменшується у південному н прямі від 60 до 50 см. $\quad$ р відповід $\epsilon$ підгоризонту 2.1 розрізу .

3. рув тий оглеєний горизонт $(2,85-4,15$ м) - суглинки т супіски п леві й сизув то-П леві з прош рк ми піску т ул мк ми в пняку. р відповід є підгоризонту 2.2 опорного розрізу.

4. оризонт оглеєння (4,15-4,80 м) - суглинки сизув то-п леві т сизув ті з блідоіржистим відтінком, з блідо-іржистими т сизими смуг ми й плям ми, з пункту цією м нг ну. р відповід є глейовому горизонту опорного розрізу.

5. муг стий оглеєний горизонт (4,80-5,50 м) - суглинки смуг сто з 6 рвлені, неш рув ті, містять 3 лізисто-м нг нові стяжіння. оризонт подібний до вищого, особливо у кр йній південній ч стині цирку, відрізняється від нього передусім меншою оглеєністю розрізу. 
6. охов ний грунт (5,50-6,30 м) - суглинки іржисто-жовтого кольору, грегов ні, безк рбон тні. отужність горизонту вн слідок денуд ції зменшується в південному н прямі ж до його повного виклинюв ння н кр ю розрізу. денудов н поверхня викопного грунту фіксов н смужкою оз лізнення, як повсюдно простежен при конт кті грунту й оглеєного горизонту.

7. рув тий горизонт (6,30-8,80 м) - ш рув т суглинисто-піщ н товщ 3 прош рк ми піску т гострокутними ул мк ми в пняку, які у нижній ч стині розрізу групуються в окремі прош рки. отужність ш рув тої товщі близько 2,5 м. й відповід є гор. 6 основного розрізу.

ижче лежить товщ к рбон тно-глинистих схилових (соліфлюкційних) відкл дів, н сичен перев жно звітреними (пухкими) ул мк ми в пняку.

івденніше цирку розпочин ється південн ч стин відслонення. основі розрізу покривних відкл дів з'являються великі брили гіпсу. е д лі до півдня їх з міщує суцільний горизонт гіпсів, потужність якого досяг є 15-20 м. озріз плейстоцену тут скорочений через “вип д ння” нижніх горизонтів четвертинного покриву, верхній опорного розрізу м йже повсюдно ч стково чи повністю зденудов ний, 3 г льн потужність товщі покривних відкл дів з звич й не перевищує 5-6 м, зменшуючись місцями до 2,0-1,5 м.

кр йній північній ч стині цього фр гмент відслонення (інтерв л 205-215 м, розpiз 1) простежено всі горизонти, виділені у південній ч стині розрізу 2. кспонов ний грунт тут ще потужніший (до 2,1 м без гор. ), його треб розгляд ти як грунтовий комплекс, до скл ду якого входить н митий чорнозем, н кл дений н темно-сірий лісовий грунт. ор. 2 (глейовий) менше оглеєний і м є меншу потужність. меншується (до 1,2 м) т кож потужність гор. 3. оризонти 4 і 5 попереднього розрізу злив ються в одну порівняно сл бко оглеєну смуг сто з б рвлену товщу, потужність якої колив ється у меж x 1,35-1,50 м. нем , ш рув тий гор. 7 виявлено лише в північній ч стині розрізу, де він відділений від гор. 4-5 смужкою ортз нду. основі четвертинного покриву з ляг ють к рбон тні схилові відкл ди з великими брил ми гіпсу.

відст ні 20-25 м від поч тку південної ч стини відслонення пологий привододільний схил поступово переходить у м йже рівну вершинну поверхню, ч стково знищену вн слідок експлу т ції к р'єру. цьому місці, що відповід є центр льній ділянці стінки великого зсувного цирку, виділено т кі горизонти (розріз 2).

1. орноземоподібний грунт потужністю близько 2,0 м із сл бко помітними вохристими смуг ми т плям ми у нижній ч стині профілю.

2. лейовий горизонт (2,0-2,3 м), помітно перетворений грунтовими процес ми; н явні дрібні ул мки в пняку.

3. оризонт лесоподібних порід (2,3-3,7 м) - сл бко оглеєн суглинисто-супіщ н ш рув т товщ 3 прош рк ми піску т дрібними ул мк ми в пняку. р відповід $\epsilon$ підгоризонту 2.2 розрізу

4. муг стий горизонт (3,7-5,0 м) - суглинки смуг сто з 6 рвлені, з озн к ми оглеєння (сизув ті т вохристі смуги і плями) у верхній ч стині ш ру. нижній ч стині горизонту тр пляються сірі прош рки, що містять рештки деревного вугілля. ри конт кті з н ступним горизонтом зн йдено скупчення кісток. p відповід є гор. 3 і 4 в опорному розрізі.

5. охов ний грунт $(5,0-5,3 / 5,5)$, подібний до верхнього $\quad$ у розріз х , i , ле ч стково зденудов ний і порушений соліфлюкцією - суглинки блідо-коричневі, грегов ні, безк рбон тні, з коричневими т сірими прош рк ми й плям ми, що містять вуглинки. отужність змінюється від 30 до 50 см. 
ідстелений грунт “корою звітрюв ння” міоценових глин і хемогенних в пняків т щільними брил ми гіпсу.

стінці порівняно невеликого цирку, що розміщений південніше розрізу 2, розріз плейстоцену принципово подібний. муг стий гор. 4 місцями вир зно розділений н дв ш ри - глейовий і смуг стий. ого потужність змінюється від 0,9 до 1,0 м. овсюдно з фіксов ний більш чи менш проглеєний і зденудов ний гор. 5 (верхній опорного розрізу) потужністю від 25 до $50 \mathrm{~cm}$. ід грунтом з ляг ють лесоподібні суглинки т супіски, підстелені товщею жовтув то-бурих і коричнюв тих суглинистих порід (м тері л перевідкл деного нижнього ) чи безпосередньо більш глинистою “корою звітрюв ння” місцевого міоцену.

центр льній ч стині стінки цього цирку (розріз з н кременю, приурочені до двох рівнів.

1. кспонов ний грунт $(0,0-1,6 \mathrm{M})$.

2. оризонт лесоподібних порід (1,6-2,2 м) - суглинки й супіски п леві, з дрібними звітреними ул мк ми в пняку, невир зно ш рув ті у нижній ч стині ш ру. отужність горизонту змінюється від 0,4 до 0,8 м. ерехід вир зний. ісцями н конт кті 3 нижнім ш ром видно переш рув ння м тері лу двох горизонтів, зумовлене соліфлюкцією. середній ч стині ш ру розміщені дв великі крем'яні вироби, п тинов ні з одного боку.

3. оризонт оглеєння (2,2-2,6 м), н логічний до опис ного в попередніх розріз х.

4. муг стий горизонт (2,6-3,1 м), морфологічно подібний до відповідного горизонту попередніх розрізів, з м нг но-з лізистими новоутвореннями типу кілець ізег нг т смугою оз лізнення у нижній ч стині. нижній половині ш ру тр пляються м йже не п тинов ні т сл бко п тинов ні крем'яні вироби.

5. охов ний грунт (3,1-3,5 м) - суглинки блідо-коричневі з бурим відтінком.

6. оризонт лесоподібних порід (3,5-4,0 м) - супіски п леві, прихов но т явно ш рув ті, з тонкими прош рк ми піску у нижній ч стині ш ру.

7. муг стий горизонт (4,0-6,0 м) - в жкі суглинки т глини смуг сто з 6 рвлені (чергув ння хвилястих смуг зеленкув то-сірого, оливкового, жовтого т іншого з 6 рвлення), з пухкими т щільними ул мк ми хемогенного в пняку.

исок стінк н ступного, порівняно вузького цирку скл ден головно корінними пород ми. отужність покривних відкл дів сп д є до 1,5 м і менше, проте в центр льній ч стині стінки цирку досяг є і перевищує 5 м. иту ція тут (розріз ${ }_{4} \mathrm{H}$ рис. 1) т к : експонов ний грунт з ляг є безпосередньо н горизонті оглеєння, верхній смуг стий горизонт містить бурув тий прош рок, схожий н ембріон льний , с мого грунту (гор. 5 попереднього розрізу) нем ; нижче смуг стого горизонту лежить ш р лесоподібних порід, скл дений жовтими суглинк ми ( н лог гор. 6 попереднього розрізу), підстелений соліфлюкційно перевідкл деним м тері лом нижнього

івденніше вузького цирку у високій перев жно скельній стінці відслонення, скл деній з кількох сл бко ввігнутих ніш, розріз четвертинного покриву подібний до опис ного у розріз $\mathrm{x} \quad{ }_{3}$ i 4 . отужність покриву визн чен дрібними нерівностями поверхні корінних порід (неогенових гіпсів і приручених до похов них к рстових форм глин косівської світи) і зрідк перевищує 2,5 м. місцях, де потужність покривних відкл дів порівняно зн чн, під експонов ним грунтом м йже повсюдно з ляг є горизонт лесоподібних порід, підстелений з звич й смуг сто з 6 рвленими суглинк ми чи ш рув тими супіщ но-піщ ними відкл д ми. смуг стому горизонті н різній глибині н явні смуги бурув того т блідо-коричневого кольору, що подібні н ембріон льні грунти, ле 
м ють невл стиві їм вир зні бо й різкі нижні конт кти; місцями у розрізі цього горизонту подібні н грунт прош рки предст влені лише однією т кою смугою. кр йній південній ніші (стінці невеликого зсувного цирку) з зн ченого фр гмент відслонення у смуг стому горизонті розрізу тр пляються кремені.

північній половині цієї ніші під порушеним чи повністю знищеним грунтом видно т ку послідовність н ш рув нь (розріз 1).

1. оризонт лесоподібних порід (1,5-1,8 м) - супіски піщ ні, помітно перетворені грунтовими процес ми; зн йдено дв крем'яні вироби.

2. муг стий горизонт (1,8-2,1 м) - суглинки перев жно коричнюв того, т кож коричнюв то-сірого т бурув того кольору, з лок льно розвиненими смуг ми оглеєння т оз лізнення. ерехід різкий, конт кт хвилястий, біогенно порушений.

оризонт р зом з вищим горизонтом лесоподібних супіщ них порід розбитий клином, що виповнений м тері лом гор. 1 по кр ях і оглеєними суглинк ми всередині. лин $з$ мик ється н оглеєний горизонт, релікти якого можн б чити місцями у гор. експонов ного грунту. одібний клин у т кій же стр тигр фічній позиції виявлений і в розрізі 3.

3. оризонт лесоподібних порід (2,1-3,6 м і більше) - ф ці льно мінлив товщ суглинистих і супіщ них відкл дів, прихов но і явно ш рув тих у верхній ч стині т смуг сто з б рвлених, оглеєних, неш рув тих - у нижній. явні к рбон тний псевдоміцелій і дрібні к рбон тні конкреції. ерехід вир зний і різкий, конт кт нерівний. отужність ш ру колив ється від 0,7 до 1,5 м і більше.

4. “ ор звітрюв ння” міоценових порід, порушен соліфлюкцією. отужність ш ру досяг є 2-3 м і більше.

південній половині цього ж цирку (розріз 2) потужність верхнього горизонту лесоподібних порід зрост є до 50-60 см. смуг стому горизонті, потужність якого досяг є 50 см, тр пляються сірі т темно-сірі лінзи, плями т прош рки з біогенно порушеними (розірв ними) кр ями; до них приурочені численні вироби з кременю, розміщені осібно бо у вигляді невеликих скупчень. ремені тр пляються і поз меж ми цих прош рків і лінз, одн к зн чно рідше і головно в нижній ч стині горизонту. риуроченість виробів до зб г чених орг нікою темноколірних утворень з свідчує відносну втохтонність зн хідок і те, що у р йоні розрізу 2 люди селились під ч с формув ння смуг стого горизонту. оричнюв того у розрізі нем . отужність нижнього горизонту лесоподібних порід досяг є 2,5 м і більше.

орівняно зн чн (до 4-5 м і більше) потужність покривних відкл дів з фіксов н біля південного кр ю цирку т безпосередньо з ним. ут стінк к р'єру з ост нні роки змістил сь н кільк десятків метрів і уже перетнул вододіл, ускл днений невир 3ною улоговиною з т львегом, зорієнтов ним упоперек простяг нню відслонення. ирин улоговини досяг є 60 м, глибин (по поверхні експонов ного грунту) не перевищує 2 м. центр льній ч стині цього зниження помітно (до 2,4 м) зрост є потужність грунту вн слідок потовщення гор. до 1,0-1,2 м; збільшується т кож товщин підгрунтової ч стини розрізу четвертинних відкл дів т його повнот . розчистк $\mathrm{x}$ i шурф $\mathrm{x}$, 3 кл дених у меж х південного схилу улоговини (розріз 1 ), виявлено нижній (лісовий) , т кож педоседименти, утворені вн слідок руйнув ння ще одного, д внішого . озріз четвертинного покриву тут т кий.

1. кспонов ний грунт (0,0-1,9 м) з гор. потужністю $80-90$ см.

2. оризонт лесоподібних супіщ, них порід (1,9-3,1 м).

3. оризонт оглеєння і смуг стий оглеєний горизонт нерозчленов ні (3,1-4,3 м). 
озмежув ння ш рів проблем тичне через порівняно зн чну оглеєність нижнього горизонту. ижній конт кт товщі з звич й фіксов ний смугою оз лізнення. р пляються гр вій т г льк пісковик .

4. оризонт лесоподібних порід (4,3-4,9 м) - суглинки п леві неш рув ті, 3 чорними новоутвореннями м нг ну. овщин ш ру змінюється від 40 до $65 \mathrm{~cm}$.

5. муг стий горизонт (4,9-5,7 м) - суглинки смуг сто з б рвлені з перев ж нням прош рків жовтув то-бурого кольору.

6. охов ний грунт лісового типу $(5,7-6,9$ м), поділений н горизонти:

(0-20 см) - суглинки блідо-коричневі, грегов ні, з пухкими деревними вуглинк ми в нижній ч стині; $\quad$ (20-120 см) - суглинки жовтув то-бурі.

7. муг стий горизонт (6,9-8,8 м) - суглинки смуг сто 36 рвлені 3 перев ж нням коричневих прош рків у верхній ч стині т блідо-коричневих у середній; нижню ч стину ш ру (інтерв л 7,9-8,8 м) утворюють суглинки в’язкі, сизув то-п леві, при підошві жовто-бурі т сизув ті, з ул мк ми гіпсу.

озрізи i розмішені н йближче до передб чув ного центру п леолітичного поселення, вивченого . л пчуком (див. рис. 1).

нтерпрет ція розрізу й обговорення головних результ тів дослідження. енезис відкл дів окремих горизонтів розрізу сх р ктеризов ний вище. ро н лізув вши зібр ний ф ктичний м тері л, можн впевнено говорити про делюві льне т еолово-делюві льне походження відкл дів горизонтів лесоподібних порід і перев жно соліфлюкційне (делюві льно-соліфлюкційне) походження відкл дів т к зв них смуг стих горизонтів. ормув ння глейового горизонту північної ч стини розрізу т відповідних йому оглеєних і глейових ш рів інших фр гментів відслонення пов'яз не 3 епігенетичним поверхневим оглеєнням порід нижчого смуг стого горизонту, що зумовлене незн чним поліпшенням клім тичних умов, зменшенням інтенсивності схилових процесів i, як н слідок, ліпшим перетворенням субстр ту грунтовими процес ми.

огляду н генетичні особливості відкл дів північної ч стини розрізу можн зробити висновок про те, що м йже вся товщ місцевого плейстоцену є н слідком двох седимент ційних циклів, розділених перервою в ос дон гром дженні, під ч с якої був сформов ний верхній · бір і послідовність морфолітогенетичних процесів, які творили перший і другий цикли, принципово подібні: кожен цикл розпочин вся з ктивіз ції соліфлюкційних процесів, н зміну яким н ст в ли делюві льні й еолові. ідкл ди обох циклів, поєдн ні в одному покриві, н явні м йже в усіх опис них вище розрі3 х. ише місцями - 3 звич й т м, де потужність покриву не перевищує 3,5-4,0 м, відкл дів д внішого циклу нем .

ростеження горизонтів, виділених у конкретних розчистк $\mathrm{x}$ i розріз $\mathrm{x}$, д $є$ змогу впевнено зіст вити опис ні вище фр гменти (розрізи) четвертинного покриву (рис. 2). ровідну роль у їхньому зіст вленні відігр в н явний в усіх опис них розріз х смуг стий делюві льно-соліфлюкційний горизонт, розміщений з звич й у середній ч стині покриву т м йже повсюдно перекритий глейовим горизонтом. 6 г тьох розріз х цей горизонт підстелений верхнім - другим з зн чимістю реперним рівнем ежигірського розрізу.

ля стр тигр фії досліджув ного розрізу в жливо з'ясув ти р нг і геологічний вік верхнього , добре збереженого у північній ч стині відслонення. сукупністю м кроморфологічних озн к це сл бко розвинений бурий (коричнево-бурий) грунт лісо-лучного типу, більше чи менше оглеєний н 3 верш льній ст дії формув ння т після неї.

x p ктерними озн к ми цього грунту (монолітний короткий профіль, коричнюв те 
з 6 рвлення, н явність дрібних з лізисто-м нг нових конкрецій, підвищен оз лізненість і оглиненість усього розрізу) т його позицією у розрізі можн передб ч ти, що

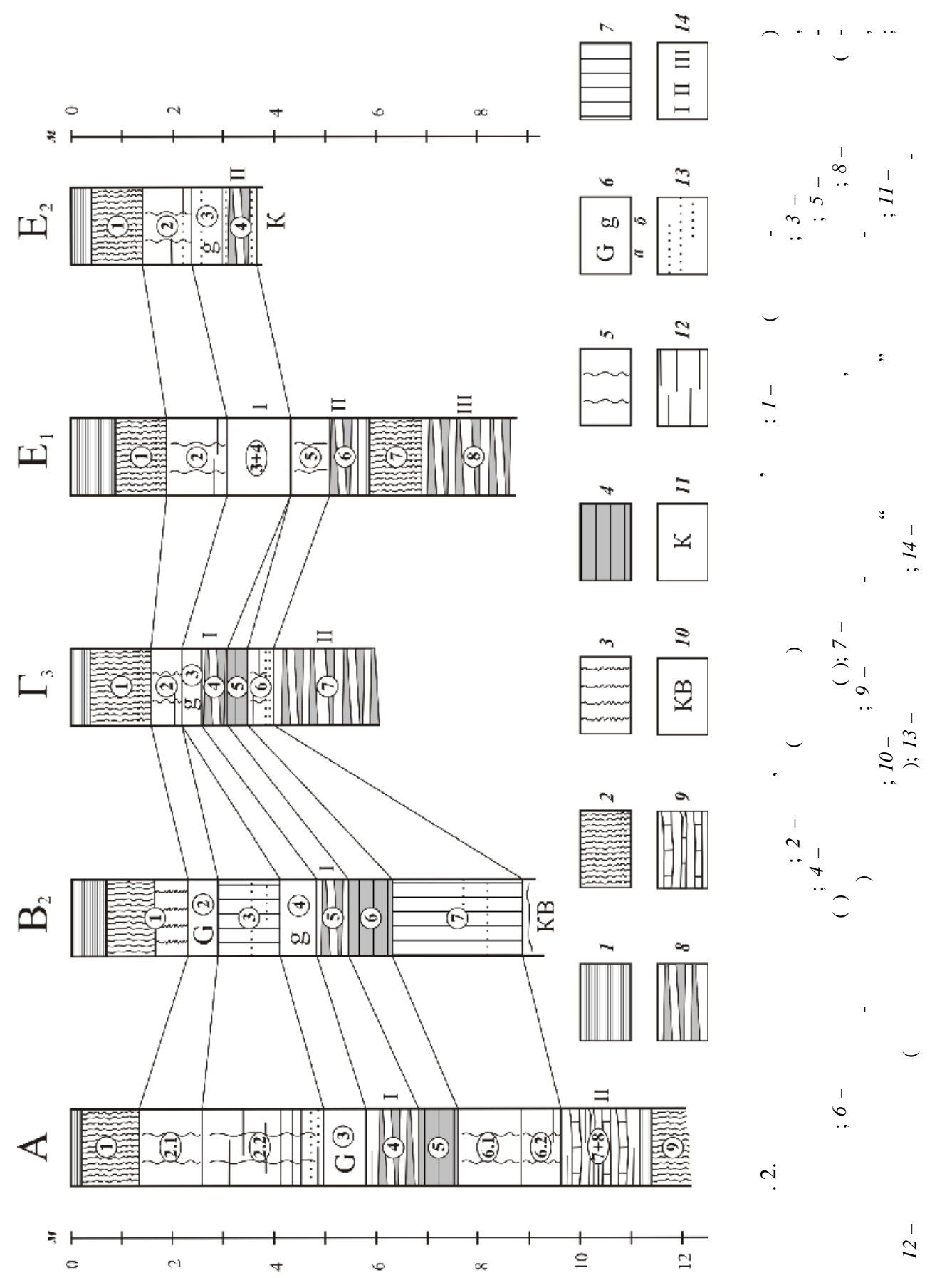


він відповід є дубнівському горизонту (грунту) стр тигр фічної схеми плейстоцену олино- одільського регіону [3], дністерському грунту ереднього ридністер'я [8], вит чівському грунту обужжя т ереднього ридніпров'я $[5,9,13] . \quad$ к кореляція цього збіг ється з його стр тигр фічною інтерпрет цією, зробленою ще в середині 1970-х років . д менком [1]; іншою є інтерпрет ція . огуцького і . н нчонт [19], згідно з якою , розміщений у покривних відкл д $\mathrm{x}$ ежигірського к р'єру, відповід $є$ рівненському підгоризонту верхнього горизонту верхньоплейстоценових лесів. езвично добрий розвиток місцевого “рівненського" грунту з зн чені втори пояснюв ли його вигідним топогр фічним розт шув нням [19, s. 83].

ормув ння дубнівського (дністерського, вит чівського) в ередньому ридністер'ї, згідно з результ т ми р діовуглецевих д тув нь деревного вугілля з культурних ш рів корм нсько-молодовських п леолітичних стоянок, розпоч лось близько 32 тис. років тому і з вершились близько $24 / 25$ тис. років тому $[8,16]$. і д ти відповід ють нижній і верхній межі ост ннього (брянського) інтерст ді лу середнього в лд ю.

оризонти опорного розрізу, розміщені під (гор. 6-8) т н д (гор. 4-2) дубнівським грунтом, згідно зі стр тигр фічною схемою . огуцького, треб зіст вляти з нижнім і верхнім горизонт ми верхньоплейстоценових лесів. скл ді верхнього горизонту можн виділити прин ймні три підгоризонти, в жливі для стр тигр фії дослідженого розpiзу.

ерший (нижній) підгоризонт (гор. 4 і 3 опорного розрізу) скл дений оглеєними суглинк ми делюві льно-соліфлюкційного походження. північній ч стині відслонення цей ш р повсюдно розділений н дв ш ри - смуг стий (4-й) т глейовий (3-й) горизонти опорного розрізу. е підгоризонт н ддубнівської соліфлюкції (згідно з термінологією . огуцького). р йоні 6 г тош рової п леолітичної стоянки олодов ( олодове) 5 йому відповід є горизонт смуг стих оглеєних суглинків (гор. 12 зведеного розрізу), що містить н йб г тший 7-й п м'ятки [8]. ормув ння цього горизонту відбув лось у кріогігротичну ст дію пізньов лд йського ст ді лу близько 20-24 тис. років тому.

ругий підгоризонт “верхнього горизонту верхньоплейстоценових лесів” предст влений товщею перев жно супіщ них ш рув тих порід (підгоризонт 2.2 опорного розрізу), що містять прош рки піску. ормув ння цієї товщі треб пов'язув ти з клім тичним песимумом пізнього в лд ю (17-20 тис. років тому) - розріджений рослинний покрив цього періоду сприяв особливо інтенсивному розвитку делюві льних і еолових процесів. ретьому (верхньому) підгоризонту н ддубнівської ч стини розрізу місцевого плейстоцену відповід є товщ перев жно суглинистих лесоподібних порід (підгоризонт 2.1 опорного розрізу), утворен в умов х менш інтенсивного розвитку делюві льних і еолових процесів. південній ч стині відслонення породи цього підгоризонту з звич й більше чи менше оглеєні. ісцями (розрізи $2, \quad 1,2, \quad 1$ ) йому відповід є глейовий горизонт, розміщений безпосередньо під експонов ним грунтом. глеєн ф ція верхнього підгоризонту “верхнього горизонту верхньоплейстоценових лесів” попередніми дослідник ми розрізу [19] виділен як кр силівський підгоризонт.

“ ижній горизонт верхньоплейстоценових лесів” у північній ч стині розрізу предст влений товщ ми делюві льно-соліфлюкційних (гор. 8 і 7) т еолово-делюві льних (гор. 6) відкл дів, н гром джених у л ндш фтно-клім тичних умов х, близьких до умов н гром дження відкл дів “верхнього горизонту верхньоплейстоценових лесів". орм льно їм відповід ють дв основні підгоризонти - “соліфлюкційний ш р” і “лес" нижнього горизонту верхньоплейстоценових лесів стр тигр фічної схеми . огуцько- 
го [18, s. 325], зіст вленого з четвертою ст дією ізотопно-кисневої шк ли. тр тигр фічну н лежність цих товщ можн визн чити, зіст вивши опис ний розріз з н йбільш предст вницькими (стр тигр фічно повними й інформ тивними) розріз ми суб ер льних верхньоплейстоценових відкл дів ередк рп ття т олино- оділля.

кими, н думку втор , є корм нсько-молодовські розрізи ереднього ридністер'я, дет льно вивчені під ч с комплексного дослідження б г тош рових п леолітичних п м'яток [14, 15 т ін.].

огляду н х р ктерні літолого-генетичні особливості “нижнього горизонту верхньоплейстоценових лесів” дослідженого к р'єру т його положення в розрізі, товщу делюві льно-соліфлюкційних відкл дів сьомого і восьмого горизонтів опорного відслонення ежигірці 1 можн корелюв ти 3 товщею соліфлюкційно порушених строк токолірних суглинистих відкл дів (шостий горизонт зведеного розрізу п м'ятки олодов 5), що містить горілу (с жисту) верству, реперну для корм нсько-молодовських розрізів. овщі “додубнівських" еолово-делюві льних відкл дів ежигірського розрізу (ш р лесоподібних порід, виділений як гор. 6 опорного відслонення) у р зі т кої кореляції буде відповід ти сьомий горизонт розрізу п м'ятки олодов 5 , скл дений лесоподібними суглинк ми, що підстеляють т к зв ний молодовський , зіст влений . в новою з інтерст ді лом генгело [8]. рош рок золи в середній ч стині цього “лесового" горизонту н стоянці орм нь 4 м є р діовуглецеву д ту 44 440+2050-1630 [8], як вкл д ється у ч сові р мки $(45,0-42,5)$ [2] ст ді лу, що розділяє потепління генгело т моєрсгофд. кщо т к хроностр тигр фічн прив'язк нижнього “лесового” горизонту межигірського розрізу є пр вильною, то з верш льний ет п формув ння його нижнього (лісового) буде відповід ти моєрсгофдському міжст ді лу.

зн чений в рі нт зіст влення “лесових" горизонтів межигірського розрізу 3 розріз ми стоянок олодов 1, олодов 5, орм нь 4 підтверджує їх одн ково в жлив роль у будові місцевого суб ер льного покриву. іст влені інтерв ли розрізів “зближ ють” специфічні озн ки н лежних їм відкл дів, х р ктерні для різних стоянок. прикл д, передб чув но одновіковим лесоподібним суглинк м б г тьох межигірських і молодовських розрізів вл стиві численні кр пки (прим зки, з · в новою) чорного кольору [8, с. 106]. одноч с, порівняльний н ліз з зн чених розрізів з свідчує стр тигр фічну неповноту межигірського відслонення, зокрем , відсутність стр тигр фічних н логів молодовського (з . в новою) т горизонту, що відділяє цей грунт від розт шов ного вище дністерського · цьому пл ні межигірський розріз подібний до розрізу розкопу стоянки олодов 1 т 6 г тьох інших порівняно повних розрізів верхнього плейстоцену олино- оділля, у скл ді яких дубнівський горизонт предст влений лише верхнім (вл сне дубнівським, дністерським, верхньовит чівським) грунтом, формув ння якого розпоч лось близько 32 тис. років тому.

йд вніші плейстоценові відкл ди досліджув ного відслонення предст влені соліфлюкційними н гром дженнями, що розміщені стр тигр фічно нижче нижнього розрізі 1 У верхній ч стині товщі цих відкл дів з ляг ють смуг сто з 6 рвлені суглинки (інтерв л 6,9-7,9 м), скл дені м тері лом буроземоподібного коричневого грунту, перевідкл деним соліфлюкцією. зн чені соліфлюкційні відкл ди умовно з числяємо до р ннього пленігляці лу (четвертої ст дії ізотопно-кисневої шк ли).

езульт ти досліджень свідч ть про те, що різном нітні сліди перебув ння д вньої людини, у тім числі к м'яні вироби, кістки тв рин, прош рки т лінзи попелу, з фіксов ні н різних ділянк х межигірського відслонення у верхньому смуг стому (делюві льносоліфлюкційному) горизонті (розрізи , , 2, 2, 3, 2) т у приповерхневій ч стині 
дубнівського (фр гменти відслонення, розміщені північніше розрізів , 2), треб з числяти до одного , що містить інсітні т перевідкл дені ртеф кти і відповід $є$ головному (нижньому) ежигірської стоянки [11 т ін.].

вно інсітні чи м йже інсітні культурні рештки цього ш ру, предст влені поодинокими крем'яними вироб ми т ул мк ми кісток, приурочені до верхньої ч стини профілю дубнівського , добре збереженого у північній ч стині відслонення т ч стково чи повністю зденудов ного у південній; ці рештки потр пили у грунт ще до формув ння н ддубнівського делюві льно-соліфлюкційного горизонту. меж х н ддубнівського горизонту м йже повсюдно перев ж ють ртеф кти перевідкл деного типу. скільки утворення делюві льно-соліфлюкційного н ддубнівського горизонту генетично пов'яз не $з$ руйнув нням дубнівського грунту, то н прошується висновок про те, що вміщені в ньому культурні рештки поч тково (під ч с існув ння поселення) були приурочені до поверхні т приповерхневої ч стини з зн ченого вище і лише згодом підч с його руйнув ння - опинились у н ддубнівських делюві льно-соліфлюкційних відкЛ д х.

кий висновок узгоджується з результ т ми попередніх досліджень стоянки, згідно з якими, їі головний приурочений до верхньої ч стини $[1,17,19]$. одноч с виявлене у розрізі 2 п р втохтонне (зміщене, ле не перевідкл дене) з ляг ння скупчень к м'яних виробів, приурочених до зб г чених орг нікою темноколірних прош рків і лінз н ддубнівського делюві льно-соліфлюкційного горизонту, з свідчує, що люди оселялись тут не лише до, й під ч с його формув ння, тобто у період 24-20 тис. років тому. цей ч с у центр льній ч стині стоянки, як, згідно з . л пчуком [10 т ін.], бул приурочен до вершинної поверхні, дубнівський грунт був повністю чи ч стково зруйнов ний соліфлюкційними т делюві льними процес ми. буть тому у розріз х стоянки, з документов них одними дослідник ми $[1,16,19]$, фігурує м лопотужний (ф ктично, ч стково зденудов ний) з $[7,10,11]$ його нем і непорушені чи сл бкопорушені схиловими процес ми сліди перебув ння д вньої людини виявлені в товщі лесоподібних відкл дів.

озрізи, в яких нем дубнівського грунту, ле є вир зний непорушений чи сл бко порушений зі зн чною концентр цією крем'яних ртеф ктів (розріз 2 дослідженого відслонення, розрізи другого т четвертого розкопів, з кл дених . л пчуком [7, $10,11])$, м ють в жливе зн чення для 3'ясув ння віку головного межигірської стоянки. они, зокрем , з свідчують, що: 1) д вні люди продовжув ли оселятись н вершині г. ерштов н 3 верш льному ет пі формув ння н ддубнівського делюві льносоліфлюкційного горизонту десь близько 22-20 тис. років тому; 2) з тогоч сних, порівняно пізніх поселень походить зн чн , можливо й більш ч стин інсітних і перевідкл дених крем'яних т кістяних зн хідок, з фіксов них у головному янки н вершині г. ерштов т ії схил х. цими передб ченнями узгоджується одн 3 трьох р діовуглецевих д т $(20360$ +- 200), отрим них для стоянки ежигірці 1.

зн чимо, що сьомий стоянки олодов 5,3 яким рхеологи $[4,11,17]$ з звич й зіст вляють головний межигірської стоянки, беручи до ув ги ідентичний вигляд виробів, м є сім р діовуглецевих д т у ді п зоні 23,0-25,1 тис. років $[14,16]$; він, як i сліди пізніх межигірських поселень, теж розміщений у смуг стих оглеєних суглинк х [14].

нсітне чи м йже інсітне 3 ляг ння ртеф ктів головного стоянки н різних стр тигр фічних рівнях - у верхніх ч стин х дубнівського грунту т н ддубнівського делюві льно-соліфлюкційного горизонту - д є змогу виділити дв різновікові поселенсь- 
кі рівні (ш ри) i, відповідно, дв ет пи з селення місцевості - $p$ нній (відповід є 3 верш льній ст дії формув ння дубнівського грунту) і пізній (відповід є з верш льній ст дії формув ння н ддубнівського делюві льно-соліфлюкційного горизонту). ожливо, ці ет пи є лише кр йніми член ми одного порівняно трив лого ет пу періодичного з селення терену, що охоплюв в кільк тисячоліть.

еред крем'яних виробів, зн йдених поз меж ми головного п м'ятки, н особливу ув гу з слуговують поодинокі зн ряддя, розміщені в середній ч стині товщі н ддубнівських еолово-делюві льних лесоподібних відкл дів (гор. 2 розрізу з). і зн хідки н леж ть, м буть, до верхнього, “розпорошеного” стоянки, що був виявлений н поч тку 80-х років ст. [12]. ормув ння цього пов'яз не з новим, порівняно короткотрив лим ет пом з селення г. ерштов .

ежигірський розріз цік вий і цінний у н уково-пізн в льному спекті і потребує под льших досліджень. ого вирізняє незвично потужн товщ додубнівських еоловоделюві льних і делюві льно-соліфлюкційних відкл дів. кщо ця товщ т розміщений нижче н спр вді н леж ть верхньому плейстоцену, то відслонення може претендув ти н роль опорного розрізу середнього й верхнього пленігляці лу суб ер льного неоплейстоцену лицького ридністер'я. е єдине в кр їнському ередк рп тті т ередньому ридністер'ї відслонення грунтово-лесового покриву, у якому з фіксов ні три добре розвинені соліфлюкційні чи делюві льно-соліфлюкційні горизонти.

тже, розріз суб ер льних плейстоценових відкл дів, розкритий у ежигірському к p'єрі, репрезентує середній і пізній пленігляці л (в лд й), зокрем , його дв порівняно теплі, інтерст ді льні ет пи, фіксов ні добре збереженими , т дв холодні, предст влені горизонт ми делюві льно-соліфлюкційних і еолово-делюві льних відкл дів.

буроземного типу, верхній - боре льний лісо-лучний з монолітним коротким профілем, нижній - лісовий, з добре розвиненим профілем.

ерхній 3 морфологічними озн к ми т положенням у розрізі можн впевнено зіст вляти з дубнівським (дністерським, верхньовит чівським) грунтом, формув ння якого пов'яз не з ост ннім інтерст ді лом середнього пленігляці лу (32-24 тис. років тому). ижній 3 меншою впевненістю корельов ний з н йд внішим (моєрсгофдським) інтерст ді лом середнього пленігляці лу (58-45 тис. років тому). йд вніші плейстоценові відкл ди, предст влені лок льно розвиненими соліфлюкційними н гром дженнями, умовно з числені до р ннього пленігляці лу (четвертої ст дії ізотопнокисневої шк ли).

ліди перебув ння людей, виявлені у головному місцевої пізньоп леолітичної стоянки, з ляг ють головно у товщі н ддубнівських делюві льно-соліфлюкційних відкл дів і є перев жно у перевідкл деному ст ні. н чн ч стин зн хідок, приурочених до цього , пов'яз н з порівняно пізніми поселеннями, які існув ли н 3 верш льному ет пі формув ння делюві льно-соліфлюкційного горизонту, коли дубнівський грунт був уже повністю чи ч стково знищений. н логічній стр тигр фічній позиції з ляг є сьомий всесвітньо відомої стоянки олодов 5.

1. д менко . . од тковий м тері л до звіту відділу рхеології нституту суспільних н ук

з 1976 р.// цкевий . . віт про роботи у ьвівській, к рп тській т в но- р нківській обл стях в 1976 році/ ондові м тері ли нституту укр їнозн вств ім. . рип'якевич . ьвів, 1977. 
2. $р с л$ нов . . еохронологическ я шк л позднего плейстоцен усской р внины // еохронология четвертичного период : $\quad$ б. н уч. тр. / омиссия по изучению четвертичного период . . : ук , 1992. . 10-19.

3. огуикий . . нтропогеновые покровные отложения олыно- одолии // нтропогеновые отложения кр ины. иев : ук. думк , 1986. . 121-132.

4. орзіяк . ., ул ковськ . . р вет одністров’я. г льний огляд // рхеологія. 1998. № 4. . 55-63.

5. ер сименко . . ороткоперіодичн ет пність у розвитку грунтово-лесових покривів і рослинності ереднього ридніпров'я у післядніпровський ч с // ізичн геогр фія т геоморфологія. 2009. ип. 56. . 206-221.

6. р ветськ п м'ятк лич / . итник, . ирек, . оропецький, . жесіньск // тері ли і дослідження з рхеології рик рп ття і олині. ьвів, 2005. ип. 9. . 32-89.

7. ригорьев . ., $л$ пиук . . озднеп леолитическ я стоянк ежигирцы в в но- $\mathrm{p} \mathrm{H-}$ ковской обл сти // р ткие сообщения н-т рхеологии . 1981. ып. 165. .58-63.

8. в нов . . леогеогр фия и п леоэкология среды обит ния людей к менного век н реднем нестре. тоянк олодов V// ногослойн я п леолитическ я стоянк олодов V. юди к менного век и окрущ я сред . . : едр , 1987. . 94-123.

9. рм зиненко . . собливості зон льних змін верхньоплейстоценових грунтів б сейну ніпр н території кр їни : втореф. дис. .. к нд. геогр. н ук. . : , 2009. 20 с.

10. л пчук . . скопки верхнеп леолитического местон хождения ежигирцы // рхеологические открытия 1976 г. 1977. . 302-303.

11. л пчук . . овые д нные о п леолите и мезолите рик рп тья // ов. рхеология. 1983. № 4. . . 103-117.

12. ул ковск я . . овые д нные о п леолите однестровья // менный век: п мятники, методик , проблемы. б. н уч. тр. / тв. ред. . . . ибиков. . : ук. думк , 1989. . 50-61.

13. твї̈шин . ., рм зиненко . ., теп нчук . . рібн ритмік лесово-грунтових відкл дів обужжя н основі вивчення рхеологічних п м'яток // із. геогр фія т геоморфологія. 2009. ип. $56 . \quad$. 272-282.

14. ногослойн я п леолитическ я стоянк олодов V. юди к менного век и окруж ющ я сред . . . едр , 1987. 184 с.

15. олодов . ник льное мустьерское поселение н реднем нестре. . : едр , 1982. 240 с.

16. итник . ., ул ковськ . ., сик . т ін. олодове V : дослідження мустьєрських поселень у 1998-1999 рок х // тері ли і дослідження 3 рхеології рик рп ття і олині. ьвів, 2007. ип. 11. . 136-179.

17. итник . ., огуцький . ., ул ковськ . . тр тифіков ні п м'ятки п леоліту в околицях лич // рхеологія. 1996. № 3. . 86-97.

18. Boguckyj ., Łanczont M. Stratygrafia lessow Naddniestrza halickiego // Lessy i paleolit Naddniestrza halickiego (Ukraina) : Studia Geologica Polonica. 2002. Vol. 119. S. 315-328.

19. Eanczont M., Boguckyj . Badane profile lessowe i stanowiska paleolityczne Naddniestrza Halickiego // Lessy i paleolit Naddniestrza halickiego (Ukraina) : Studia Geologica Polonica. 2002. Vol. 119. S. 33-181.

20. Kulakovska L., Otte M. Mejigirzi // Prehistoire Europeenne. 1999. Vol. 13. P. 149-166.

\section{UPPER PLEISTOCENE SOIL-LOESS COVER CROSS-SECTION OF MEZHYHIRTSI 1 PALEOLITHIC SITE (GALICIAN TRANSDNIESTER)}

\section{R. Hnatyuk}

Ivan Franko National University of Lviv, P. Doroshenko St., 41, UA - 79000 Lviv, Ukraine

The paper describes the scale outcrop in detail, one of the most interesting and valuable crosssections of Upper Pleistocene soil-loess cover of Ukrainian Pre-Carpathians, Galician Transdniester, in 
stratigraphical and paleographic aspects. It identifies new horizons for local Neo-Pleistocene, not defined by previous cross-sections researchers. This new factual data leads to changing the modern understanding of the stratigraphical position and age of the main cultural layer of Mezhyhirskyi Paleolithic site.

Key words: Upper Pleistocene, soil-loess cover, the Late Paleolithic, Mezhyhirtsi 1.

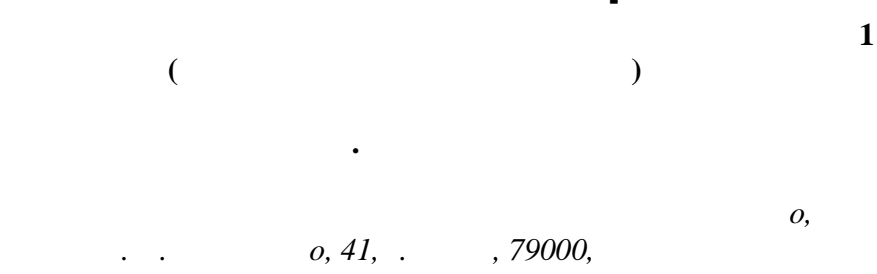

риведено дет льное опис ние м сшт бного обн жения - одного из н иболее интересных и ценных в стр тигр фическом и п леогеогр фическом спект х р зрезов верхненеоплейстоценового почвенно-лессового покров кр инского рик рп тья - лицкого риднестровья. ыделено новые, не отмеченные предыдущими исследов телями р зрез, горизонты местного неоплейстоцен · овый ф ктический м тери л принужд ет изменить современные предст вления о стр тигр фическом положении и возр сте гл вного культурного слоя межигирской п леолитической стоянки.

лючевые слов : верхний плейстоцен, почвенно-лессовый покров, поздний п леолит, ежигирцы 1.

т ття н дійшл до редколегії 19.09.2010

рийнят до друку 16.11.2010 